\title{
Design and Development of a Prilled Urea Applicator
}

\section{Subrata Paul', Mohammad Abdur Rahman1, Bidhan Chandra Nath ${ }^{2}{ }^{\circledR}$, Anwar Hossen', A. K. M. Saiful Islam¹, M. Kamruzzaman Milon', M. Kamruzzaman Pintu1}

${ }^{1}$ Farm Machinery and Postharvest Technology Division, Bangladesh Rice Research Institute, Gazipur, Bangladesh

${ }^{2}$ School of Civil Engineering and Surveying, University of Southern Queensland, Queensland, Australia

Email: ^bidhanbrri@gmail.com, bidhan.nath@usq.edu.au

How to cite this paper: Paul, S., Rahman, M.A., Nath, B.C., Hossen, A., Islam, A.K.M.S. Milon, M.K. and Pintu, M.K. (2021) Design and Development of a Prilled Urea Applicator. Agricultural Sciences, 12, 530-548. https://doi.org/10.4236/as.2021.125034

Received: March 29, 2021

Accepted: May 17, 2021

Published: May 20, 2021

Copyright (c) 2021 by author(s) and Scientific Research Publishing Inc. This work is licensed under the Creative Commons Attribution International License (CC BY 4.0).

http://creativecommons.org/licenses/by/4.0/

\begin{abstract}
A prilled urea applicator was designed and developed to increase fertilizer use efficiency. The developed applicator's aims to place Urea continuously at the subsurface of soil between two rows of plants. A line-to-line distance of 20 $\mathrm{cm}$, depth of prilled urea placement of $5-7 \mathrm{~cm}$, and field operating condition at $1-1.5 \mathrm{~cm}$ standing water (for softening the field) was the designed hypothesis. At the laboratory and farm level, test the developed applicator. The applicator consists of a rectangular frame, two skids and furrow opener, two cylindrical hoppers, and a drive wheel connected with a metering device. The designed applicator was fabricated using PVC, except the push handled (mild steel). The metering device consists of twelve spikes and is made of a metallic plate to apply the Urea uniformly. The applicator has a furrow opener and closer options. The effective field capacity was $0.13 \mathrm{ha} / \mathrm{h}$ with a speed of $1.22 \mathrm{~km} / \mathrm{h}$ and field efficiency of $98 \%$. Due to the continuous falling mechanism, there is no missing option but found the over-falling urea for both hoppers was found $5.35 \%$. The average depth of urea placement was $6.38 \mathrm{~cm}$. The machine was user-friendly to push, and the mean pushing force was $63.89 \mathrm{~N}$. The weight of the applicator was $9 \mathrm{~kg}$. So, it is natural to carry from one field to another field. The applicator is also convenient to handle, operate and manage.
\end{abstract}

\section{Keywords}

Prilled Urea, Applicator, Deep Placement, Urea Use Efficiency, Capacity

\section{Introduction}

Nitrogen is one of the most yield-limiting nutrients in rice production worldwide, especially in tropical Asian soils. Almost every farmer must apply the 
costly $\mathrm{N}$ fertilizer to get a desirable rice yield [1] [2]. Urea is the most convenient form of fixed nitrogen in many ways. It has the highest nitrogen content (46\%) available in a solid fertilizer [3]. Solid fertilizer, as well as prills formation, is easy for manufacturing. In contrast, prilled urea transportation is convenient in bulk or bags and no explosive hazards like liquid nitrogen.

Prilled Urea is the most popular fertilizer used for rice production in Asia. Urea's application method in the fields depends on the types (size and shape) of fertilizer [2]. It is classified by fine (prilled) and super granular (USG/UMG) type [3]. Usually, farmers of Bangladesh, India broadcast fine Urea by hand in the field [4]. Generally, total growing periods of the crop farmers use urea 2 to 3 times. The traditional application efficiency of prilled Urea fertilizer is typically $30 \%$ to $50 \%$ [3] [5] [6]. Urea is lost in various ways, such as ammonia volatilization, denitrification, leaching, seepage, and surface runoff [7].

In Bangladesh, the most popular fertilizer method is broadcasting. During broadcasting, only $40 \%$ of the applied Urea is used by the plant, and the remaining $60 \%$ is lost by air, water, or leached under the ground [8]. Sometimes, broadcasted Urea is mixed with irrigation water and contaminated the aquaculture system [4]. Several countries (Japan, China, Bangladesh, etc.) and organizations (IRRI, BRRI, IFDC, etc.) have been developed deep placement applicator with USG (Urea Super Granule) and UMG (Urea Mega Granule) for improving fertilizer use efficiency. However, globally undertook a minimal initiative with a prilled urea applicator.

A journey of food security and mitigate the environmental impacts need to improve the management of plant nutrients (fertilizer) [2]. Fertilizers (mainly Urea) and grain yield have a positive correlation [9]. Fertilizer deep placement, especially the urea deep placement, has been commonly recognized as an effective management practice for transplanted rice productivity and reduces fertilizer use [10]. For instance, deep placement of urea increase nitrogen use efficiency up to $50 \%$ to $70 \%$, increase grain yield $15 \%$ to $20 \%$ and reduces $\mathrm{N}$ fertilizer use by $30 \%$ to $40 \%$ [11] [12]. Kapoor et al. [13] noted that the broadcast application of prilled Urea resulted in higher amounts of nitrogen losses in floodwater than the deep placement of Urea. Hence, a deep place of Urea has not only an agronomic impact but also an environmental benefit through reducing volatilization and denitrification losses [14].

The International Fertilizer Development Center (IFDC) has been taking huge activities for making a larger size of Urea as (USG, UMG) with deep placement [15]. However, the preparation of USG/UMD is a complicated and storage problem. Heading the nitrogen use efficiency, the Bangladesh Rice research institute (BRRI) and Bangladesh Agricultural Research Institute (BARI) developed a USG applicator [3]. All these are pushing the USG inside the soil surface. However, objectively all designed applicators have some common difficulties such as high missing rate due to dropping problems, blockage of the discharge pipe-need additional power required to operate, high self-weight-fully loaded, 
soil bearing capacity is not sufficient to facilitate the even movement of the wheel of muddy soil [15]. Consequently, USG misses losing the yield, and farmers have not shown a willingness to use the USG. Besides, USG fabrication briquette machines are not commercially available.

In conclusion, USG fertilizer, as well as an applicator for rice cultivation suitably and user friendly. In contrast, deep placement of USG by hand after transplanting is a slow field operation, thus, requiring much labour (6 - 8 personday/ha) [4] [16]. Likewise, labour intensiveness and drudgery of placing have seriously limited USG adoption by rice farmers in South and Southeast Asia [5]. Regarding the above issues, rural farmers are not interested in using USG fertilizer, but available forms of urea fertilizer (prilled) are user friendly. Therefore, concerning the aforementioned problems, the present study aims to design and develop a prilled urea applicator.

Rice is a principal staple food of Bangladesh and meets $80 \%$ of food demand [17] [18] [19] [20]. Urea is an emerging necessary nitrogen fertilizer for rice production and in countries, $80 \%$ urea (prilled) is used by the rice [15]. The conservative use of Urea needs to minimize the loss and a deep placement (5 - 10 $\mathrm{cm}$ ) is the best solution [7]. Wohab et al. [6] noted that a mechanical device is necessary to increase the nitrogen application efficiency and minimize tedious labour work. Nath et al. [20] mentioned that for sustainable rice production the mechanized farming in utmost necessary, especially fertilizer application. There are a few types of research on mechanizing nitrogen fertiliser application in wetland, but no one is efficient. It also reduced the $\mathrm{N}$ transfer to water instantly, and plant roots can gradually uptake the deeply placed fertilizer [13].

Moreover, deep placement of nitrogen fertilizer into the anaerobic soil zone is an effective method to reduce volatilization loss [3] [21] [22]. In this context, an applicator machine is needed to place prilled Urea $6-7 \mathrm{~cm}$ deep under the sub-surface of soil between the consecutive two lines. The expected developed "prilled urea applicator" will be accepted by the farmers due to the low energy requirement, reduced urea requirement, ease of operation, and increase rice production.

\section{Materials and Methods}

\subsection{Design Considerations}

Considered the following factors in designing prilled urea applicator (PUA): 1) machine should be as simple and easy to operate, assemble, dis-assemble, and maintain; 2) depth of fertilizer placement should be $5-7 \mathrm{~cm}$; 3) line to line spacing should be adjustable; 4) the cost of the machine need to be within the capacity of rural small farmers; 5) ensured the covering of prilled Urea; 6) a single person should operate it; and 7) lightweight for easy handling.

The applicator designed with field line to line spacing of $20 \mathrm{~cm}$, and the distance between two skids was $40 \mathrm{~cm}$ (centre to centre). The prilled urea applicator was fabricated using locally available materials. Prilled Urea (PU) is chemically 
the same as fine Urea; however, size is less or more equal. Since the physical properties (size, diameter, bulk density) of the Urea are similar, it has no chance of spillage/blockage from the aperture on the hopper wall (Table 1). The physical properties were used to design the fertilizer meter units' component [23]. Moreover, the actual capacity of each hopper is $1500 \mathrm{~g}$, but it is $1000 \mathrm{~g}$ maintained to prevent overlapping.

\subsection{Design and Development of Different Parts of Applicator}

The complete and different views of the BRRI prilled urea applicator are shown in Figure 1 and Figure 2. The manual push type PUA was designed and fabricated in the Farm Machinery and Postharvest Technology (FMPHT) divisional research workshop of Bangladesh Rice Research Institute (BRRI), Bangladesh. The manual push type PUA consists of the following major parts: skid, metering device, hopper, drive wheel, and frame with a handle. During design, all components of the applicator were modified by the trial and error method. The PUA is made with plastic (Poly Vinyl Chloride (PVC)), except an adjustable part of the frame and handle. The PVC is readily available, durable, and long-lasting.

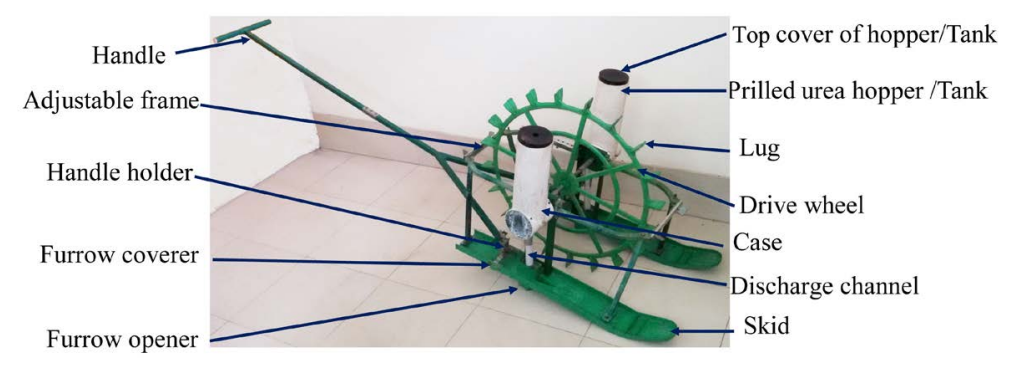

Figure 1. Photographic view of the prilled urea applicator.

Table 1. The specification of prilled urea.

\begin{tabular}{llc}
\multicolumn{1}{c}{ Parameter } & & Value/specifications \\
\hline Nitrogen concentration & $:$ & $46 \%$ (Minimum) \\
Moisture content & $:$ & $05 \%$ (Maximum) \\
Biuret & $:$ & $1.4 \%$ (Maximum) \\
Granulation & $:$ & $2-3 \mathrm{~mm}$ \\
Melting point & $:$ & $132^{\circ} \mathrm{C}$ \\
Colour & $:$ & Standard white \\
Radiation & $:$ & Non-radioactive \\
Diameter & $:$ & $2-4 \mathrm{~mm}$ \\
Weight of 10 granule (uniform size and shape) & $:$ & $0.22 \mathrm{gm}$ \\
Disappear Time & $:$ & $2-2.5 \mathrm{~h}(\mathrm{In} \mathrm{water})$ \\
Disappear Time & $:$ & $72-78 \mathrm{~h}(\mathrm{In}$ the air) \\
Bulk density & $:$ & $700-800 \mathrm{~kg} / \mathrm{m}^{3}$ \\
Angle of repose & $:$ & $35^{\circ}$ \\
\hline
\end{tabular}




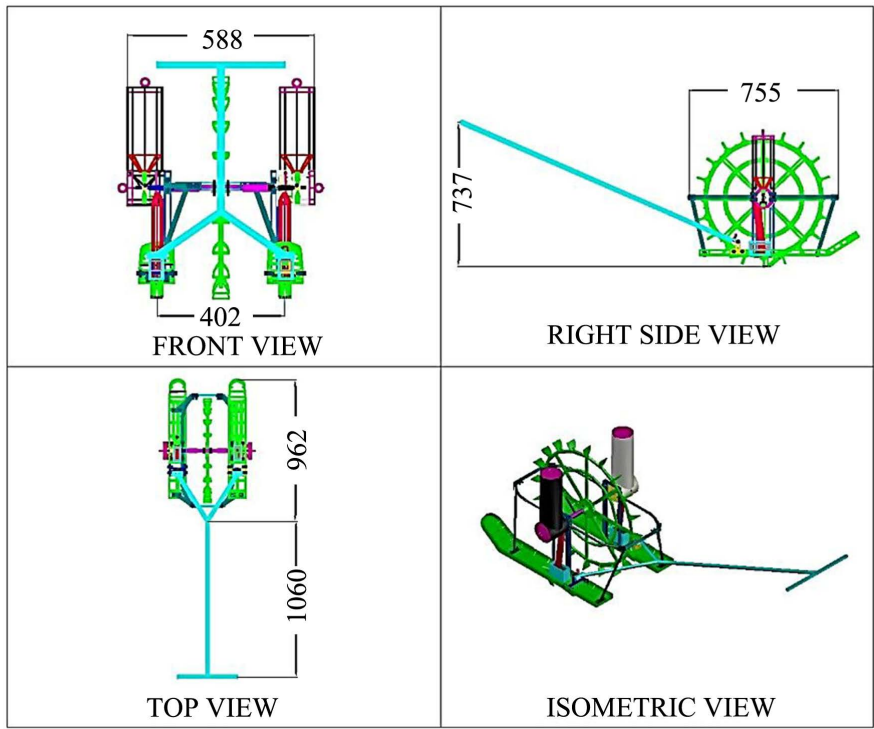

Figure 2. Different views of prilled urea applicator.

The descriptions of different significant parts are given here in:

1) Skid: Two skids help the applicators to protect from penetration into soft muddy soil and smoothly to move. The skid also assists in sharing the dispersed weight load of the applicator. The total length and width of the skid were critically selected, 83.5 and $11.5 \mathrm{~cm}$, respectively. The inclined part, furrow opener, and furrow closer are an integral part of the skid (Figure 3 and Figure 4). The front inclined part was arranged with 32-degree angles with the skid to facilitate the applicator's running. Also, the furrow opener's inclined shape protected the muddy soil from entering into the opener and secured clogging. Moreover, the inclination parts length was $17 \mathrm{~cm}$. The applicator's furrow opener was connected at the bottom of the skid, maintaining a sliding angle of 47 degrees. It helps to make a furrow easily. $6.0 \mathrm{~cm}$ height and $8.7 \mathrm{~cm}$ length of furrow opener was designed that allows granules dispensed easily to the field. The furrow closer inclination was 8 degrees with $8.5 \mathrm{~cm}$ length, and $1.2 \mathrm{~cm}$ height assists the furrow closed with soft soil.

2) Metering Mechanism: Disk diameter was $10.2 \mathrm{~cm}$, with 12 spikes/teeth connected at the outer edge (Figure 5 and Figure 6). The cups help dispense Urea to the output channel from a cylindrical hopper (Figure 3(a)). The thickness and width of the teeth of the metering device were $2.0 \mathrm{~mm}$ and $10 \mathrm{~mm}$, respectively. The outer and internal diameter of the metering device was 100 and $86 \mathrm{~cm}$, respectively. The drive wheel is directly connected to the metering device. Moreover, the urea dispensing rate and drive wheel speed were simulated to the recommended urea fertilizer rate. Also, for easy dispensing of prilled Urea to the applicator's channel, an impeller was connected below the tank, as well as a metering device that conveyed Urea without clogging. The length and width of the impeller were 9.8 and $1.6 \mathrm{~cm}$. Both sides of the impeller were twisted about $35^{\circ}$ angles with its horizontal axis (Figure 5), an essential part of the machine. 


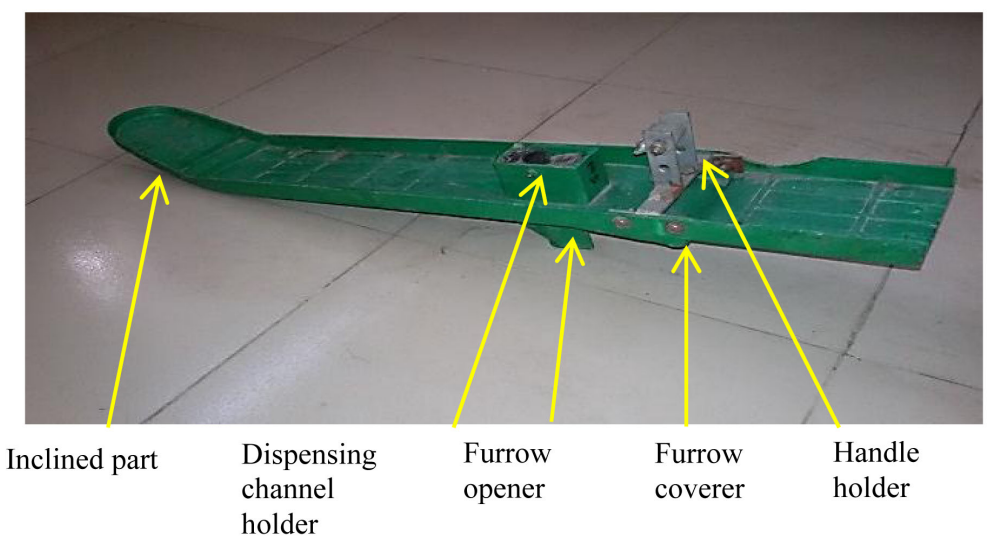

Figure 3. Photographic view and left side view of the skid with furrow opener and coverer.

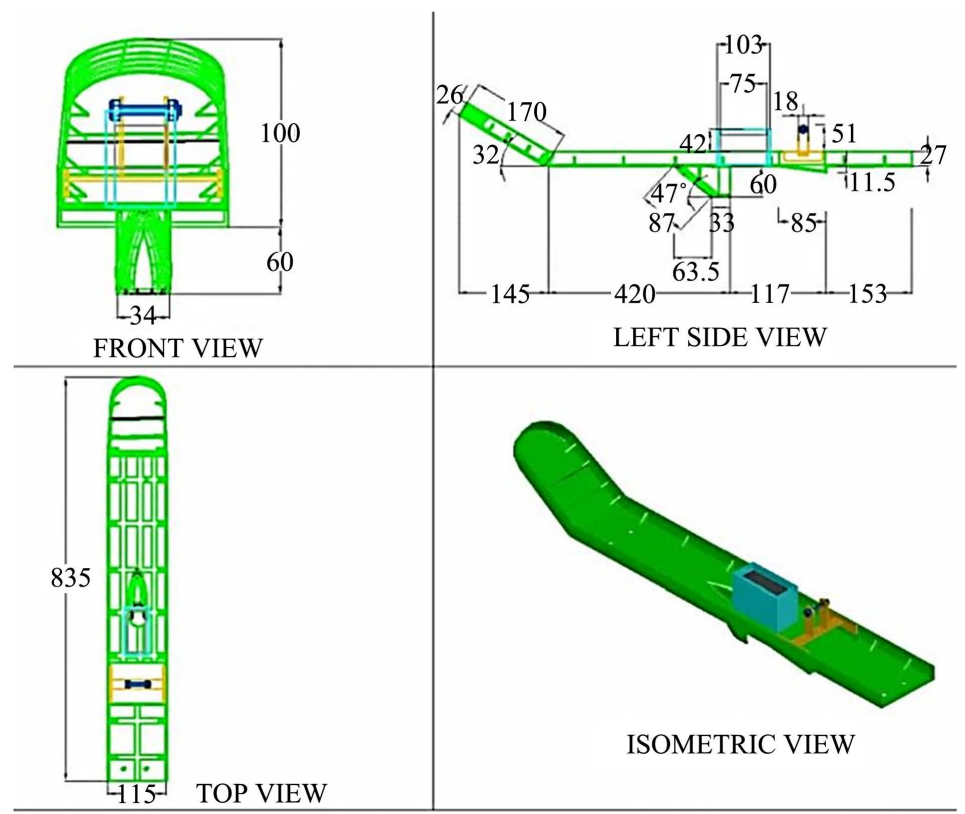

Figure 4. Different views of the skid with furrow opener and coverer. (All dimensions are in $\mathrm{mm}$ ).

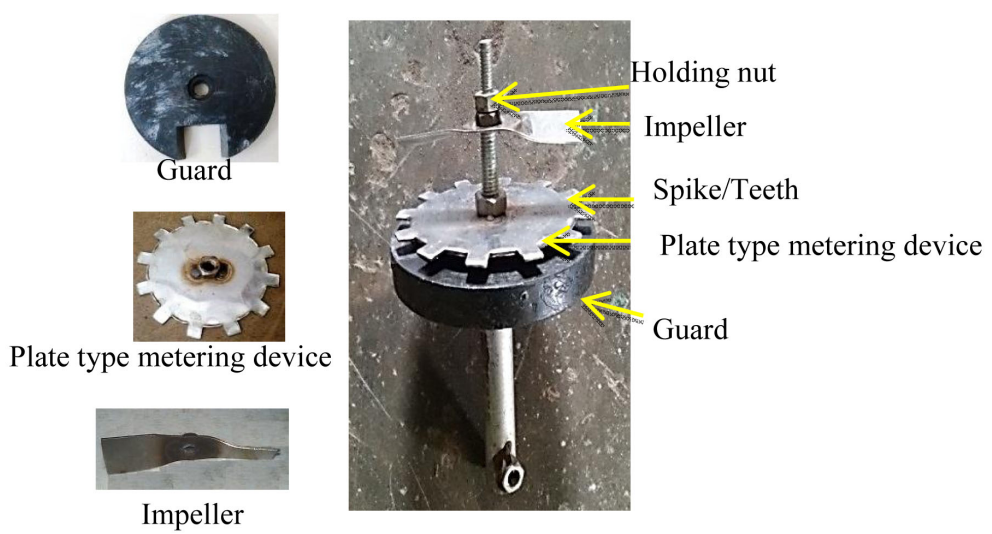

Figure 5. Photographic view of the metering device with impeller and guard. 


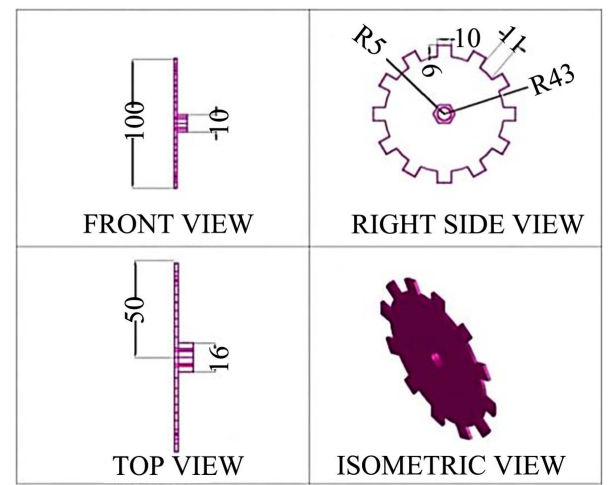

(a)

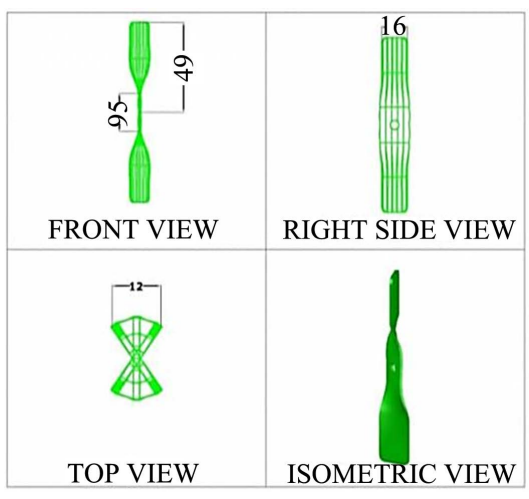

(b)

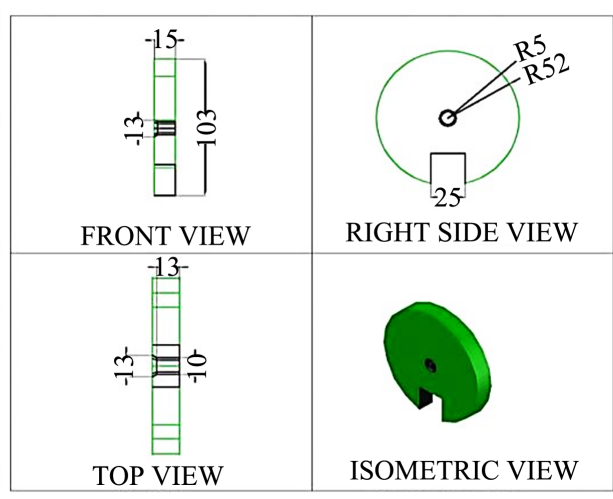

(c)

Figure 6. Different views of the plate type metering mechanism (All dimensions are in $\mathrm{mm}$ ). (a) Different views of metering disk; (b) Different views of impeller; (c) Different views of guard.

The dispensing rate of Urea depends on its adjustment. In this applicator, the gap between the impeller centre and discharge outlet lever has readjusted to increase pressure on the urea release lever without changing the impeller. If pressure increases on the urea release lever, then it opens more and dispenses more Urea. The gap between the impeller centre and release lever for Boro rice season varieties and Aman/Aus season varieties were $19 \mathrm{~mm}$ and $37 \mathrm{~mm}$, respectively. The adjustment is made by using three (03) nuts. The fertilizer is controlled by nuts as 3 nuts Boro season and 2 nuts for Aus/Aman season added below in the impeller.

3) Hopper with Funnel, Case, Side Guard and Discharge Channel: The capacity of each hopper was about $1500 \mathrm{gm}$. (Figure 7 and Figure 8). The hopper's height and diameter were 31.5 and $11.0 \mathrm{~cm}$, respectively, with round tapering at the bottom. The hopper was attached to the case/dispensing chamber, whose diameter was $11.0 \mathrm{~cm}$. The funnel of the tank was attached on a $3.3 \mathrm{~cm}$ diameter hole, and a small hole of $1.1 \mathrm{~cm}$ diameter was found at the bottom of the dispensing chamber. Moreover, a funnel (larger diameter $10.2 \mathrm{~cm}$, smaller diameter $3.2 \mathrm{~cm}$, and height $5.5 \mathrm{~cm}$ ) was attached at the bottom of the hopper. The discharge tube was attached under the small hole of the dispensing chamber. The 


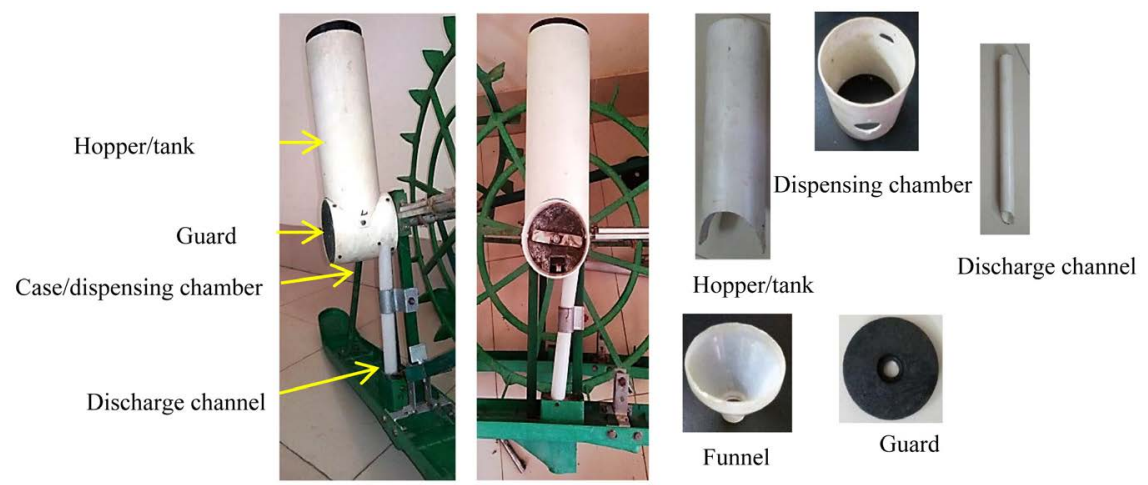

Figure 7. Photographic view of the hopper, funnel, dispensing chamber, guard and discharge channel.

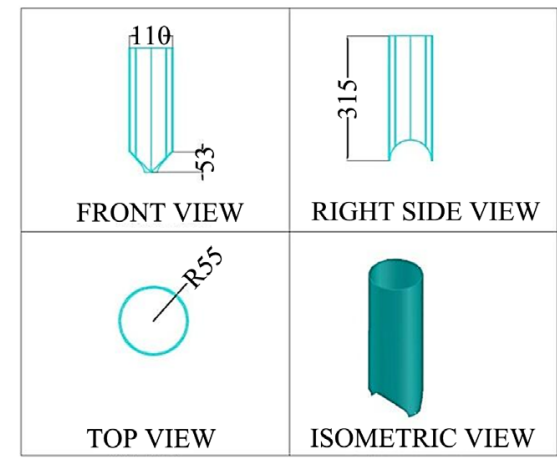

(a)

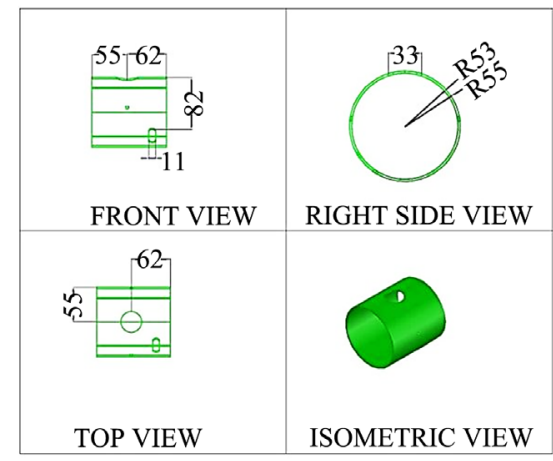

(c)

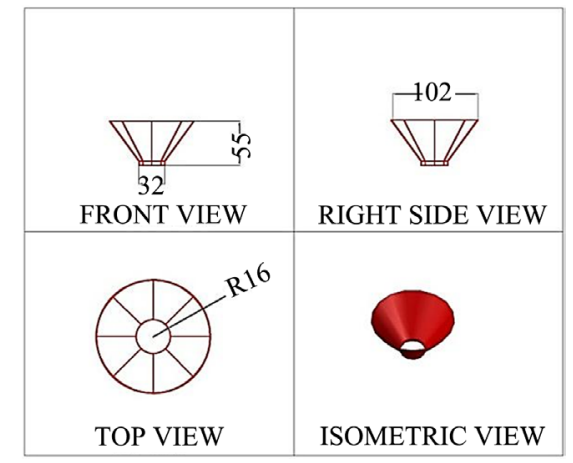

(b)

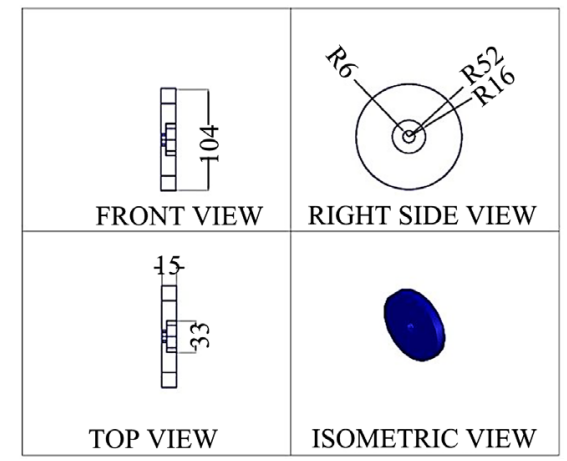

(d)

Figure 8. Different views of the granules hopper/tank unit assembly. (All dimensions are in mm). (a) Different views of hopper/tank; (b) Different views of funnel; (c) Views of dispensing chamber; (d) Different views of side guard.

discharge tube and hopper were made of plastic, and thickness was $2.5 \mathrm{~mm}$. The height and diameter of the dispensing tube were 27 and $2.5 \mathrm{~cm}$, respectively. The top of the hopper was cover to protect falling Urea from the top.

4) Drive Wheel: The diameter and periphery of the drive wheel were 61.0 and $192.0 \mathrm{~cm}$, respectively. Due to direct coupling, the metering device can rotate with the rotation of the drive wheel. As a result, PU was collected from the hopper continuously and dispensed in $192 \mathrm{~cm}$ distance per one cycle of the drive 
wheel (Figure 9). The driving wheel also worked as a power transmission device to put the dropped PU into the soil. Adjust 20 lugs on the periphery of the driving wheel, which makes traction during field operation. During operation, the developed traction depends on the applicator's lug dimensions, soil condition, and weight. The lugs dimension was determined by trial and error basis view of different soil conditions and the applicator's weight. The width and height of the lug were the same $(5.0 \mathrm{~cm})$.

5) Frame with Handle: The frame is an essential component for holding different parts as a skid, handle, drive wheel, and hopper of the applicators (Figure 10). The structure was made of plastic, and the handle was made of mild steel (MS) road. The length, height, and width of the frame were $75.1,34.0$, and $47.3 \mathrm{~cm}$, respectively. The structure was tightened with skids and a driving wheel using a nut and bolt. The handle is made of a round pipe of $163.5 \mathrm{~cm}$ in length and attached with a V shape connector (Figure 11). The length of the handle is $7.5 \mathrm{~cm}$, which is connected with the skid. To hold the discharge tube tightly between the mainframes and skid used two rectangular shape frames.

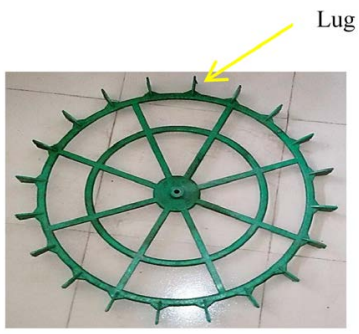

(a)

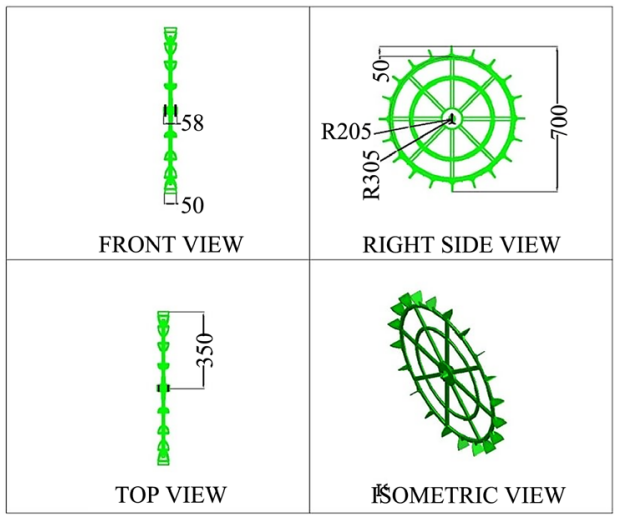

(b)

Figure 9. Different views of the drive wheel. (All dimensions are in $\mathrm{mm}$ ).

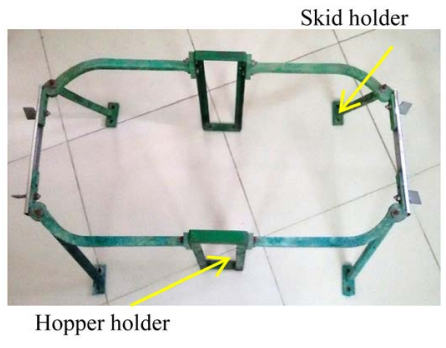

(a)

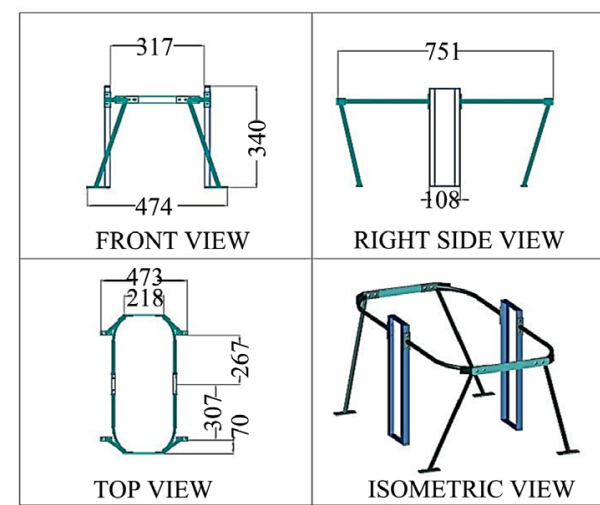

(b)

Figure 10. Different views of the main structure of prilled urea applicator. (All dimensions are in $\mathrm{mm}$ ). (a) Photographic view of main structure; (b) Isometric view of main structure. 


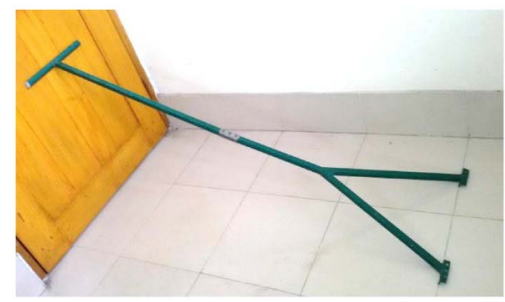

(a)

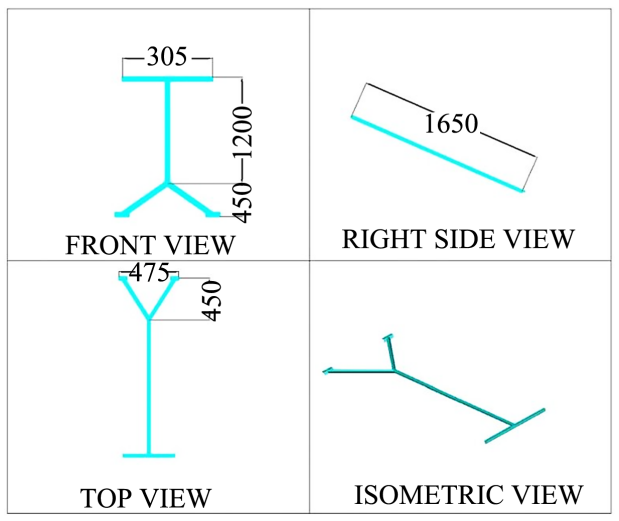

(b)

Figure 11. Different views of applicator handle. (All dimensions are in $\mathrm{mm}$ ). (a) Photographic view of handle; (b) Isometric views of handle.

\subsection{Operational Pre-Conditions}

For better performance, several operational procedures should be followed, such as:

$\phi$ Handle height differs with the operator's height, so height adjustment is a significant issue for effective operation in the field;

$\phi$ The PUA design force is pushing. Any kinds of pulling will create a blockage in the furrow opener as well as Urea dispensing channel;

$\phi$ Minimum standing water $(0.5-1 \mathrm{~cm})$ need to maintain during field operation. It will help to keep the soil soft that helps the applicator for smooth running with proper furrow opening and closing;

$\phi$ The walking speed should be standard $(1.72 \mathrm{~km} / \mathrm{h})$.

\subsection{Recommended Fertilizer Rate}

As urea fertilizer is a prime source of nitrogen for rice cultivation, it varies with season, climatic condition, and soil fertility status. The rice-growing season is classified as Aus, Aman, and Boro, likely the fertilizer rate also differs. The Bangladesh Rice Research Institute (BRRI) recommendation rate of urea fertilizer for Bangladesh is $220 \mathrm{~kg} / \mathrm{ha}$ in Boro and $140 \mathrm{~kg} / \mathrm{ha}$ in Aus/Aman season. The developed PUA has an impeller by which can be controlled the dispensing rate. The PUA was designed for urea application rate $8-9 \mathrm{~kg} / 10$ decimal for Boro and $5-6 \mathrm{~kg} / 10$ decimal for the Aus/Aman season (70\% of the recommended rate). For field application, the impeller with the drive wheel was adjusted until the urea dispense rate in each tube of 13.5 - $14 \mathrm{gm}$ for Boro and $9-10 \mathrm{gm}$ for Aus/Aman season for each revolution of the drive wheel.

\subsection{Working Principles of PUA}

When an operator pushes the applicator by the handle, the forward movement of the machine skids and driving wheel assist in rotating the metering device in the hopper. The teeth conveyed the PU from the hopper and dropped on the 
dispensing tube. After that, the urea enters to subsurface furrow, which is made by an opener. When the application moves forward, the urea is covered by the furrow closer. Figure 12 represent the laboratory and field operations of PUA.

\subsection{Theoretical Considerations}

The theoretical concerns were studied by [3] [16]. The leading factors for the performance evaluation of PUA include the weight of an applicator, capacity, dispensing rate, depth of placement, over falling percentage, walking speed, field capacity, field condition, ease of operation, adjustment of the applicator, soil type, land topography, field size, and shape, etc.

\subsubsection{Weight of Prilled Urea Applicator}

The weight of the applicator is significant to carry and for smooth operation. So it was trying to keep the weight of the applicator as low as possible. During the operation, the weight of Urea in the hopper also included applicator weight. A digital balance measured the weight of the applicator and the weight of Urea in the hopper, and data was recorded. The weight of the applicator is $9.0 \mathrm{~kg}$.

\subsubsection{Applicator Capacity}

The weight of dropped Urea per unit time or area was considered the capacity of the applicator. The applicator was set up on a high platform for easing to move the drive wheel for determination of capacity. Two plastic bowls were kept below the two discharge tubes of metering devices. One person rotates the wheel 20 times as equivalent to the standard walking speed $(1.78 \mathrm{~km} / \mathrm{h})$ in the puddled field [4]. A stopwatch recorded the time required for 20 revaluations. Then, the weight of Urea which was collected in each bowl was measured with a balance. The following equation estimated the capacity of an applicator.

$$
\text { The capacity of the applicator }=\frac{W}{T}(\mathrm{~kg} / \mathrm{h})
$$

where,

$$
\begin{aligned}
& W=\text { total weight of Urea dropped }(\mathrm{kg}) \\
& T=\text { time to operate the applicator }(\mathrm{h})
\end{aligned}
$$

\subsubsection{Field Capacity}

The effective field capacity may be defined as the field's actual rate when the

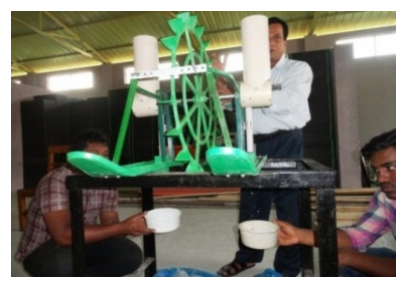

(a)

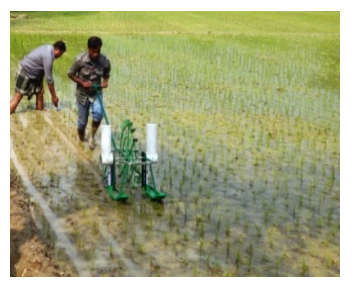

(b)

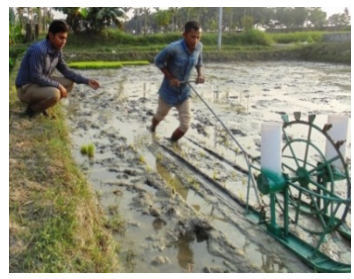

)

Figure 12. Performance test of the applicator. (a) Laboratory testing; (b) Operation in field condition. 
applicator was operated within a specified time. The theoretical and effective field capacity of the applicator was calculated as follows:

$$
\text { Theoretical field capacity }(\mathrm{TFC})=\frac{S W}{10}(\mathrm{ha} / \mathrm{h})
$$

where,

$$
\begin{aligned}
& S=\text { forward speed }(\mathrm{m} / \mathrm{h}) \\
& W=\text { width of coverage }(\mathrm{m}) \\
& \quad \text { Effective field capacity }(\mathrm{EFC})=\frac{\text { Actual field coverage }}{\text { Actual time of operation }}(\mathrm{ha} / \mathrm{h})
\end{aligned}
$$

$$
\text { Field efficiency }=\frac{\mathrm{TFC}}{\mathrm{EFC}} \times 100
$$

\subsubsection{Missing or Over Falling Rate}

The hoppers of the applicator were filled with Urea, and the metering device was rotated for one minute by turning the wheels. The number of turns was counted, and time was by a stopwatch. Dropping Urea was also measured and recorded. The experiment was done by four (04) times. Then the missing and over a falling percentage of Urea were calculated using the following equation.

$$
\text { Missing or over falling }=\frac{N * Y-X}{N * Y} \times 100
$$

where,

$$
\begin{aligned}
& N=\text { number of turns of the wheel per minute } \\
& Y=\text { weight of urea per turns }(\mathrm{kg}) \\
& X=\text { weight of Urea fallen per minute }(\mathrm{kg})
\end{aligned}
$$

\subsubsection{Push Force $(P)$}

The required forces to push the applicator were determined in the field using a spring balance. Spring balance was fixed in the frame and pulled the applicator. The height and horizontal length by pulling were measured by tape for calculating the pulling angle $(\alpha)$, as shown in Figure 13. In the finals, the draft $(d)$ was determined using the following equation.

$$
\operatorname{Draft}(d)=P \cos \alpha
$$

\section{Results and Discussion}

\subsection{Capacity of the Applicator}

Operator walking speed, land condition, soil type, operator strength, and skill influence an applicator's capacity. Varying levels of walking speed were set up to determine the capacity of laboratory conditions and presented in Table 2. The average capacity and walking speed of the machine were $0.16 \mathrm{ha} / \mathrm{h}$ and 1.99 $\mathrm{km} / \mathrm{h}$ for Aus and Amon season, respectively. On the contrary, for Boro season, $0.16 \mathrm{ha} / \mathrm{h}$ and $2.02 \mathrm{~km} / \mathrm{h}$ where the capacity and walking speed, respectively. 


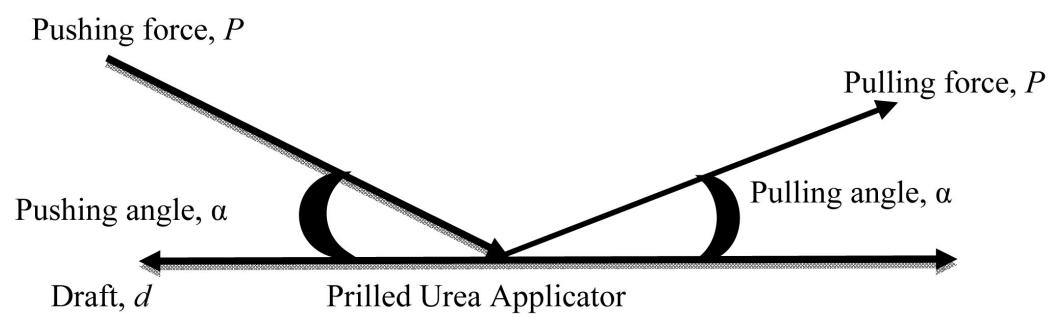

Figure 13. Forces diagram.

Table 2. Design capacity of the PUA (Aus/Aman season).

\begin{tabular}{|c|c|c|c|c|c|c|}
\hline \multirow{2}{*}{$\begin{array}{l}\text { Trial } \\
\text { No. }\end{array}$} & \multirow{2}{*}{$\begin{array}{c}\text { Hopper } \\
\text { Urea } \\
\text { holding } \\
\text { capacity, g (a) }\end{array}$} & \multirow{2}{*}{$\begin{array}{c}\text { Amount of } \\
\text { Urea in } \\
\text { hopper after } \\
\text { operation, } g(b)\end{array}$} & \multirow{2}{*}{$\begin{array}{l}\text { Amount } \\
\text { of Urea } \\
\text { released, } \\
g(a-b)\end{array}$} & \multicolumn{2}{|c|}{ Design Capacity } & \multirow{2}{*}{$\begin{array}{c}\text { Operating } \\
\text { speed } \\
(\mathrm{km} / \mathrm{h})\end{array}$} \\
\hline & & & & $\mathrm{kg} / \mathrm{h}$ & $\mathrm{ha} / \mathrm{h}$ & \\
\hline \multicolumn{7}{|c|}{ Aus/Aman season } \\
\hline 1 & \multirow{4}{*}{2000} & 1640 & 360 & 21.60 & 0.168 & 2.07 \\
\hline 2 & & 1677 & 323 & 19.98 & 0.156 & 1.96 \\
\hline 3 & & 1696 & 304 & 18.24 & 0.147 & 1.84 \\
\hline 4 & & 1649 & 351 & 21.06 & 0.166 & 2.07 \\
\hline \multicolumn{4}{|c|}{ Average } & 20.22 & 0.16 & 1.99 \\
\hline \multicolumn{4}{|c|}{ Standard deviation } & 1.4818 & 0.0097 & 0.1096 \\
\hline \multicolumn{7}{|c|}{ Boro season } \\
\hline 1 & & 1435 & 486 & 29.16 & 0.166 & 2.07 \\
\hline 2 & \multirow{3}{*}{2000} & 1320 & 532 & 31.92 & 0.175 & 2.19 \\
\hline 3 & & 1180 & 493 & 29.58 & 0.157 & 1.96 \\
\hline 4 & & 1088 & 472 & 28.32 & 0.147 & 1.84 \\
\hline \multicolumn{3}{|c|}{ Average } & & 29.75 & 0.16 & 2.02 \\
\hline \multicolumn{3}{|c|}{ Standard deviation } & \multicolumn{2}{|c|}{1.5417} & 0.0120 & 0.1497 \\
\hline
\end{tabular}

\subsection{Field Capacity}

The field capacity of the applicator was measured in the BRRI research field on a trial basis. Time was recorded, including turning and losing time. During field testing incorporating three different labour and measured total distance. The average field capacity was $0.13 \mathrm{ha} / \mathrm{h}$ (Table 3 ).

\subsection{Missing and Overfalling of Urea}

The size and shape of the Urea mostly uniform, because average weight of 10 granules is $0.22 \mathrm{gm}$ (Table 1); hence the weight of Urea not varied significantly. Due to the Urea's shape, there is no possibility to block the dispensing passage and missing. The over falling were determined and presented in Table 4. The over falling percentage of both hoppers was $5.35 \%$. Overfill occurred due to small sizes, low speed, and shaking because of the uninformed walking speed in both the hoppers. 
Table 3. Field capacity.

\begin{tabular}{cccc}
\hline Total time, min & Travelling distance, $\mathrm{m}$ & Speed, $\mathrm{km} / \mathrm{h}$ & Capacity, ha/h \\
\hline 7 & 198 & 1.70 & 0.136 \\
9 & 236 & 1.57 & 0.126 \\
8 & 212 & 1.59 & 0.127 \\
& & 1.22 & 0.13 \\
\hline
\end{tabular}

N.B: Constant effective width $=80 \mathrm{~cm}$.

Table 4. Over falling percentage of urea.

\begin{tabular}{ccccc}
\hline $\begin{array}{c}\text { No of turns } \\
\text { per minute }(N)\end{array}$ & $\begin{array}{c}\text { Weight of Urea } \\
\text { per turn (gm), } Y\end{array}$ & $N^{*} \boldsymbol{Y}$ & $\begin{array}{c}\text { Total weight of fallen } \\
\text { Urea per minute }(\mathrm{kg}), \boldsymbol{X}\end{array}$ & $\begin{array}{c}\text { Over falling }= \\
\frac{(N * Y-X)}{(N * Y)} * 100\end{array}$ \\
\hline 18 & 28 & 504 & 480 & 4.76 \\
16 & 26.5 & 424 & 400 & 5.66 \\
17 & 29 & 493 & 470 & 4.66 \\
17 & 27 & 459 & 430 & 6.32 \\
\end{tabular}

\subsection{Urea Dispensing Efficiency}

Urea dispensing efficiency was measured in the laboratory. The applicator was set up on a high platform for easing to move the drive wheel for the dispensing test. Each hopper was filled with $1.5 \mathrm{~kg}$ of PU. The drive wheel was rotated 20 times continuously at an average speed of $2.0 \mathrm{~km} / \mathrm{h}$; the dispensed Urea was collected from the bottom of the output channel. This method was applied separately for Aus/Aman and Boro's recommended rate. Dispensing efficiency was measured by weighing the gather of dispensing Urea. Average dispensing efficiency was $98.52 \%$ for Aus/Aman season and $98.63 \%$ for Boro (Table 5).

\subsection{Depth of Urea Placement}

The prime aim of the study was to place the PU at the desired depth for increasing the nitrogen use efficiency. The depth of placement varied on soil conditions and the penetration of the applicator. Different depth of urea placement was found during the operation is presented in Table 6. The average Depth of PU placement was $6.38 \mathrm{~cm}$.

\subsection{Pushing Force}

Field-tests outcomes of pushing force, necessity are presented in Table 7. With the machine weights of $11 \mathrm{~kg}$ (including Urea), the mean pushing force was found at $63.89 \mathrm{~N}$, which suggests the ease of handling of the applicator. Pushing 
Table 5. Results of the laboratory test.

\begin{tabular}{ccccc}
\hline \multirow{2}{*}{$\begin{array}{c}\text { Number of } \\
\text { rotations }\end{array}$} & \multicolumn{2}{c}{ Amount of urea dispense (gm) } & \multicolumn{2}{c}{ (\%) of dispensing } \\
\cline { 2 - 5 } & Aus/Amon & Boro & Aus/Amon & Boro \\
\hline 495 & 690 & 99.0 & 98.57 \\
20 & 492 & 692 & 98.4 & 98.86 \\
& 488 & 688 & 97.6 & 98.29 \\
& 498 & 686 & 99.6 & 98.00 \\
& 490 & 696 & 98.0 & 99.43 \\
& Average & & 98.52 & 98.63 \\
\hline
\end{tabular}

Table 6. Result of depth measurement of the placed Urea during operation.

\begin{tabular}{ccccc}
\hline $\begin{array}{c}\text { Number of } \\
\text { observations }\end{array}$ & $\begin{array}{c}\text { Highest depth, } \\
\mathbf{c m}\end{array}$ & $\begin{array}{c}\text { Lowest depth, } \\
\mathbf{c m}\end{array}$ & $\begin{array}{c}\text { Average depth, } \\
\mathbf{c m}\end{array}$ & Remarks \\
\hline 5 & 7 & 5 & 6.0 & \\
5 & 8 & 6 & 7.0 & $\begin{array}{c}\text { The depth of } \\
\text { placement varied } \\
\text { due to different } \\
\text { penetration of } \\
\text { the skid }\end{array}$ \\
5 & 8 & 5 & 6.5 & 6.0 \\
& 7 & 5 & 6.38 & \\
& Average & & 0.478 & \\
\hline
\end{tabular}

Table 7. Push force requirement.

\begin{tabular}{ccccc}
\hline $\begin{array}{c}\text { Observation } \\
\text { no. }\end{array}$ & $\begin{array}{c}\text { Pulling force } \\
(\mathrm{kg})\end{array}$ & $\begin{array}{c}\text { Pulling angle } \\
\text { (degree) }\end{array}$ & $\begin{array}{c}\text { Pulling force/ } \\
\text { Pushing force (N) }\end{array}$ & $\begin{array}{c}\text { Average } \\
\text { pushing force (N) }\end{array}$ \\
\hline 1 & 7.8 & 35 & 62.68 & \\
2 & 8.4 & 35 & 67.50 & 63.89 \\
3 & 8.0 & 35 & 64.29 & \\
4 & 7.6 & 35 & 61.07 & \\
\hline
\end{tabular}

force is extremely correlated with two leading issues, such as the weight of the PUA and the amount of moisture in the muddy soil.

\subsection{General Specifications}

The weight of the applicator is $9 \mathrm{~kg}$ (without Urea), which is easy to carry from one field to another field. The pushing force was $63.89 \mathrm{~N}$, which was based on a pushing angle of $35^{\circ}$. Consequently, one man and woman can push the applicator very easily. The fabrication of the applicator is also easy and simple. It has the advantage of necessarily less energy and easy to adjust and operate. The overall specification of the applicators is shown in Table 8 and Table 9. 
Table 8. Details of the developed PUA.

\begin{tabular}{|c|c|c|}
\hline & Parts & Specification \\
\hline \multirow{3}{*}{ Skid } & No & 2 \\
\hline & Length, $\mathrm{cm}$ & 83.5 \\
\hline & Width, cm & 11.5 \\
\hline \multirow{3}{*}{ Furrow opener } & Inclination, degree & 47 \\
\hline & Height, cm & 6.0 \\
\hline & Opening width, $\mathrm{cm}$ & 3.4 \\
\hline \multirow{2}{*}{ Furrow closer } & Inclination, degree & 8 \\
\hline & Width, $\mathrm{cm}$ & 11.5 \\
\hline \multirow{5}{*}{ Drive wheel } & No & 1 \\
\hline & Diameter, $\mathrm{cm}$ & 61.0 \\
\hline & Periphery, $\mathrm{cm}$ & 192 \\
\hline & No of lug & 20 \\
\hline & Lug dimension (height and width), $\mathrm{cm}$ & 5 \\
\hline \multirow{3}{*}{ Metering device } & No & 2 \\
\hline & Plate diameter, $\mathrm{cm}$ & 10.0 \\
\hline & No of spike/teeth & 12 \\
\hline Frame & Dimension (height, width, and length), $\mathrm{cm}$ & $34 \times 75.1 \times 74.5$ \\
\hline Handle & Length, $\mathrm{cm}$ & 165 \\
\hline
\end{tabular}

Table 9. Complete specifications of PUA.

\begin{tabular}{lll}
\multicolumn{1}{c}{ Particulates } & \multicolumn{1}{c}{ Description } \\
\hline Name & $:$ Push type prilled urea applicator \\
Source of power & $:$ Manual \\
Source of power for driving & $:$ Manually push \\
Metering mechanism & $:$ Driving wheel \\
Weight of the machine & $:$ kg \\
Overall dimension (length, width, and height) & $:$ & $20.2 \mathrm{~cm} \times 58.8 \mathrm{~cm} \times 34.0 \mathrm{~cm}$ \\
No. of operator required & $:$ & 1 \\
Average travelling speed & $:$ & $1.62 \mathrm{~km} / \mathrm{h}$ \\
Metering system & $:$ & $12 \mathrm{cups}$ rotate with disk \\
The capacity of each hopper & $:$ & $1.5 \mathrm{~kg}$ \\
Materials of the skid, metering device, driving wheel & $:$ & Plastic \\
The material of the metering device & & Stainless steel \\
Materials of frame and handle & $:$ Plastic and Mild Steel Pipe \\
PU dropping mechanism & $:$ Gravitational forces \\
The recommended line to line distance & $: 20 \mathrm{~cm}$ \\
Average push force & $: 63.89$ \\
Theoretical field capacity & $: 0.19$ \\
Actual field capacity & $: 0.13 \mathrm{ha} / \mathrm{h}$. \\
Field efficiency & $98 \%$ \\
\hline
\end{tabular}


Table 10. Cost analysis of the applicator.

\begin{tabular}{|c|c|c|}
\hline \multirow{2}{*}{ Parameter } & \multicolumn{2}{|c|}{ Amount } \\
\hline & TK & US\$ \\
\hline Cost of the applicator & 6000 & 70.59 \\
\hline The working life of the applicator & 5 years & 5 years \\
\hline Capacity (ha/yr, considering 20 working days per season) & 68.64 & 68.64 \\
\hline Interest on investment, depreciation, and others cost, $\mathrm{Tk} / \mathrm{yr}$ & 1080 & 12.71 \\
\hline Working time $\mathrm{h} / \mathrm{yr}$ & 480 & 480 \\
\hline Wages of one labor $\mathrm{Tk} / \mathrm{hr}$ & 65 & 0.7647 \\
\hline Total fixed cost, $\mathrm{Tk} / \mathrm{yr}$ & 1590 & 18.71 \\
\hline Effective field capacity, ha/h & 0.13 & 0.13 \\
\hline Total variable cost, $\mathrm{Tk} / \mathrm{h}$ & 65.438 & 0.7699 \\
\hline $\begin{array}{l}\text { Total operating cost, Tk/ha (including Fertilizer cost (30\% less) @ } \\
173 \text { kg/ha (R Recommended Dose of BRRI: } 247 \text { Kg/Ha, price: Tk.18/kg) }\end{array}$ & 3642.84 & 42.86 \\
\hline $\begin{array}{l}\text { Traditional cost Tk/ha (considering } 0.405 \mathrm{ha} / \mathrm{h} \text { and Tk 500/man-day) } \\
\text { (Fertilizer cost @ } 247 \mathrm{~kg} / \mathrm{ha} \\
\text { Recommended Dose of BRRI: } 247 \mathrm{Kg} / \mathrm{ha} \text {, price: Tk.18/kg) }\end{array}$ & 4606.55 & 54.195 \\
\hline Save over traditional, $\mathrm{Tk} / \mathrm{ha}$ & 963.70 & 11.34 \\
\hline Payback period, $\mathrm{h}$ & 862.06 & 862.06 \\
\hline Machine versus Traditional cost ratio & 1.26 & 1.26 \\
\hline
\end{tabular}

Note: Average work day $=8 \mathrm{hr}$ at 0.13 ha per hr.; Labor/operator charge $=500 \mathrm{Tk} /$ day, 1 US $\$=85 \mathrm{BD}$ TK.

\subsection{Economic Performance}

The cost analysis of the PUA is presented in Table 10. The price of the applicator varied with the quality of the materials. The working life of the applicator was considered five years. The operating cost of the applicator was $3642 \mathrm{Tk} / \mathrm{ha}$ (43 USD), however, the traditional (manually application) cost was over 4000 $\mathrm{Tk} / \mathrm{ha}$ (54 USD).

\section{Conclusion}

BRRI prilled urea applicator was designed in the research workshop with a view to the deep placement of prilled Urea between two rows of the plant as well as a farmer can also save Urea about 30\%. The operating principle of the BRRI prilled urea applicator was user friendly and the overall performance of the applicator was effective for the application of prilled urea deep placement in the field. The field capacity of the applicator was $0.13 \mathrm{ha} / \mathrm{h}$, whereas manual application capacity was $4-5 \mathrm{decimal} / \mathrm{h}$ based on labor skill. Minimum standing water is required to operate the applicator in the field. The applicator was suitable to place the prilled Urea continuously in the line transplanted rice field. The farmer can use this machine for getting the benefit of yield advantages using less amount of fertilizer. 


\section{Conflicts of Interest}

The authors declare no conflicts of interest regarding the publication of this paper.

\section{References}

[1] Saleque, M., Abedin, M., Bhuiyan, N., Zaman, S., and Panaullah, G. (2004). LongTerm Effects of Inorganic and Organic Fertilizer Sources on Yield and Nutrient Accumulation of Lowland Rice. Field Crops Research, 86, 53-65. https://doi.org/10.1016/S0378-4290(03)00119-9

[2] Rahman, S.M.M., Kamruzzaman, M., Alam, M.R., Nath, B.C. and Raihan, A.T.M.Z. (2010) Development of a Deep-Placement Fertilizer Applicator. International Journal of Bioresearch, 8, 17-22.

[3] Hossen, M.A., Islam, M.S., Rahman, M.A., Huda, M.D., Bhuyain, M.G.K and Nath, B.C. (2013) Design and Development of a Manually Operated Urea Super Granule (USG) Applicator. Agricultural Mechanization in Asia, Africa, and Latin America, 44, 85-91.

[4] Karim, M.F., Alam, M., Ali, M.R. and Kozan, O. (2015) Design and Development of a Drum Seeder with Urea Supergranule Application for Rural Farmers in Bangladesh. Agricultural Engineering International: CIGR Journal, 17, 61-71.

[5] Savant, N.K., Ongkingco, P.S., Zarate, I.V., Torrizo, F.M. and Stangel, P.J. (1991) Urea Briquette Applicator for Transplanted Rice. Fertilizer Research, 28, 323-331. https://doi.org/10.1007/BF01054333

[6] Wohab, M.A., Gaihre, Y.K., Ziauddin, A.T.M. and Hoque, M.A. (2017) Design, Development and Field Evaluation of Manual-Operated Applicators for Deep Placement of Fertilizer in Puddled Rice Fields. Agricultural Research, 6, 259-266. https://doi.org/10.1007/s40003-017-0267-5

[7] Miah, M.A., Gaihre, M.Y.K., Hunter, G., Singh, U. and Hossain, S.A. (2016) Fertilizer Deep Placement Increases Rice Production: Evidence from Farmers' Fields in Southern Bangladesh. Agronomy Journal, 108, 805-812. https://doi.org/10.2134/agronj2015.0170

[8] Islam, A.S., Rahman, M., Rahman, A.L., Islam, M. and Rahman, M. (2015) Field Performance Evaluation of Push Type Prilled Urea Applicator in Rice Cultivation. Bangladesh Rice Journal, 19, 71-81. https://doi.org/10.3329/brj.v19i2.28167

[9] Prasad, R. and Datta, S.K. (1978) Increasing Fertilizer Nitrogen Efficiency in Wetland Rice (in tropical Asia). Nitrogen and Rice Symposium, College, Laguna, Philippines, 18-21.

[10] Bandaogo, A., Bidjokazo, F., Youl, S., Safo, E., Abaidoo, R. and Andrews, O. (2014) Effect of Fertilizer Deep Placement with Urea Supergranule on Nitrogen Use Efficiency in Sourou Valley (Burkina Faso). Nutrient Cycling in Agroecosystems, 102, 79-89. https://doi.org/10.1007/s10705-014-9653-6

[11] Alam, M.M., Karim, M.R., and Ladha, J.K. (2013) Integrating Best Management Practice for Rice with Farmers' Crop Management Techniques: A Potential Option for Minimizing Rice Yield Gap. Field Crops Research, 144, 62-68. https://doi.org/10.1016/j.fcr.2013.01.010

[12] International Fertilizer Development Center (IFDC) (2013) Fertilizer Deep Placement. IFDC Solutions. International Fertilizer Development Center, Muscle Shoals, AL. 
https://issuu.com/ifdcinfo/\%20docs/fdp_8pg_final_web?e=1773260/1756718\%20(A ccessed\%202\%20December\%202020)

[13] Kapoor, V., Singh, U., Patil, S.K., Magre, H., Shrivastava, L.K. and Mishra, V.N., et al. (2008) Rice Growth, Grain Yield, and Floodwater Nutrient Dynamics as Affected by Nutrient Placement Method and Rate. Agronomy Journal, 100, 526-536. https://doi.org/10.2134/agronj2007.0007

[14] Savant, N.K. and Stangel, P.J. (1990) Deep Placement of Urea Supergranules in Transplanted Rice: Principles and Practices. Fertilizer Research, 25, 1-83. https://doi.org/10.1007/BF01063765

[15] Hasan, M.M., Rahman, M.A. and Rabbani, M.A. (2018) Design and Development of Manually Push-Type Urea Super Granule Applicator. Agricultural Engineering International: CIGR Journal, 20, 80-87.

[16] Ahmed, M.R., Billah, M.M. and Ziauddin, A.T.M. (2013) Battery Operated USG Applicator. Progressive Agriculture, 23, 75-80. https://doi.org/10.3329/pa.v23i1-2.16618

[17] Nath, B.C., Hossen, M.A., Islam, A.K.M.S., Huda, M.D., Paul, S. and Rahman, M.A. (2016) Postharvest Loss Assessment of Rice at Selected Areas of Gazipur District. Bangladesh Rice Journal, 20, 23-32. https://doi.org/10.3329/brj.v20i1.30626

[18] Gaudin, R. (2012) The Kinetics of Ammonia Disappearance from Deep-Placed Urea Supergranules (USG) in Transplanted Rice: the Effects of Split USG Application and PK Fertilizer. Paddy and Water Environment, 10, 1-5. https://doi.org/10.1007/s10333-011-0249-3

[19] Gaudin, R. and D'Onofrio, G. (2015) Is the Source-Sink Relationship in Transplanted Rice Receiving Deep Placed Urea Supergranules Dependent upon the Geometry of Transplanting? Paddy and Water Environment, 13, 433-442. https://doi.org/10.1007/s10333-014-0461-Z

[20] Nath, B.C., Nam, Y.S., Huda, M.D., Rahman, M., Ali, P. and Paul, S. (2017) Status and Constrain for Mechanization of Rice Harvesting System in Bangladesh. Agricultural Sciences, 8, 492-506. https://doi.org/10.4236/as.2017.86037

[21] Mandal, K. G., Thakur, A. K. and Ambast, S.K. (2019) Current Rice Farming, Water Resources and Micro-Irrigation. Current Science, 116, 568-576.

[22] Nath, B.C., Bhuiyan, M.G.K., Haque, M.M., Chanda, D., Rahman, M.A. and Shozib, H.B. (2019) Use of Zn Enriched Rice By-Product as Zn Fertilizer. Journal of Agricultural Engineering, 42, 58-62.

[23] Aulakh, M.S. and Bijay-Singh. (1996) Nitrogen Losses and Fertilizer N Use Efficiency in Irrigated Porous Soils. Nutrient Cycling in Agroecosystems, 47, 197-212. https://doi.org/10.1007/BF01986275 